Article

\title{
Radon as a Natural Tracer for Monitoring NAPL Groundwater Contamination
}

\author{
Martina Mattia ${ }^{1}$, Paola Tuccimei ${ }^{1, *}$, Michele Soligo ${ }^{1}$ and Claudio Carusi ${ }^{2}$ \\ 1 Dipartimento di Scienze, Università “Roma Tre”, 00154 Rome, Italy; martina.mattia@uniroma3.it (M.M.); \\ michele.soligo@uniroma3.it (M.S.) \\ 2 Protezione Ambiente, Mares S.r.l., 00144 Rome, Italy; claudiocarusi@maresitalia.it \\ * Correspondence: paola.tuccimei@uniroma3.it
}

Received: 29 September 2020; Accepted: 24 November 2020; Published: 26 November 2020

check for updates

\begin{abstract}
In this research, the radioactive noble gas radon was used as a tracer for Non-Aqueous Phase Liquids (NAPLs) contamination, since it is much more soluble in these substances than in air or water. Soil radon remains trapped within the NAPLs, resulting in a local reduction in the radon concentration within close proximity to the contaminated area. This technique was applied to a contaminated site in Roma (Italy). The main residual NAPLs are total hydrocarbons and methyl-tertiary-butyl ether (MTBE), a water-soluble additive. The monitoring activities included two sampling campaigns of groundwater from 18 wells in February and May 2020. Concentration maps were produced using radon data. The results show that the radon deficit traces the location of NAPLs in the fuelling station very well, with a residual source zone extending in a NNW-SSE direction. A good correspondence between a low amount of radon and a higher concentration of NAPLs was found. A reduction in the average amount of radon in the May 2020 survey indicated a stronger remobilization of NAPLs compared to that of the February 2020 monitoring campaign. The peaks of Volatile Organic Compounds (VOCs) detected between 8-9 and 11-12 m depths indicate the presence of residual blobs of NAPLs in the vadose zone of the aquifer.
\end{abstract}

Keywords: NAPLs; radon; groundwater contamination; monitoring; MTBE; geochemical tracer

\section{Introduction}

The monitoring and detection of organic contaminants-e.g., Non-Aqueous Phase Liquids (NAPLs) - in the subsoil using geochemical and non-invasive methods are crucial due to the direct and strong impact that these substances have on groundwater resources. Indeed, NAPLs may persist in the subsurface for a long period, thus becoming long-term sources of groundwater contamination. Therefore, effective remediation planning requires the identification and assessment of residual NAPLs in the subsoil or contaminants dissolved in groundwater to form a NAPL plume. Geochemical tracers such as radon gas are often used to study the spatial distribution of residual contaminants in aquifers and to deduce information on subsoil contamination [1,2].

Radon is a naturally occurring radioactive noble gas. Due to its ubiquitous presence in nature, its chemical and physical properties, and its straightforward detectability, radon fulfils all the requirements for use as an environmental tracer [2,3]. The equilibrium radon concentration in the pore space of an aquifer or soil depends on the aquifer emanation coefficient, the aquifer porosity, the radium activity concentration, and the bulk density of the mineral matrix [4].

Radon is usually employed to trace NAPL contamination in soil and groundwater because of its remarkable solubility in these substances. Radon gas is much more soluble in a wide range of these contaminants than in air or water. Consequently, as it rises towards the interface with the atmosphere it remains trapped within the pure residual NAPLs, but not necessarily in an aqueous solution of BTEX 
(Benzene, Toluene, Ethylbenzene and Xylene) or MTBE, for example, and produces a concentration deficit compared to nearby unpolluted sites. The mapping of this process, known as the radon-deficit technique [1,2,5-16], allows observers to identify the contamination affecting either the vadose or the saturated portions of an aquifer. This topic has been addressed using a steady-state radon partitioning model and a one-dimensional model for radon transport with NAPL partitioning $[1,17,18]$. Both approaches are based on some assumptions, such as a homogeneous ${ }^{226} \mathrm{Ra}$ distribution in the aquifer rock, a constant porosity, no ${ }^{222} \mathrm{Rn}$ loss, equilibrium ${ }^{222} \mathrm{Rn}$ partitioning between the NAPLs and the water phase, and a negligible ${ }^{222} \mathrm{Rn}$ sorption from the matrix. These need to be demonstrated and accounted for in any single situation [6].

Other works have dealt with modification [19] by the aging and biodegradation of NAPLs in aquifers [20,21]. An excellent review of these, with an extensive list of related references, has recently been published [2].

In this context, the present work is mainly a case study, and its purpose is to verify and support the potential of the radon-deficit technique to assess contamination by NAPLs in a study area located in Roma (Italy).

\section{Study Area}

\subsection{Geological Setting}

At the study site, located in the south-east portion of Roma (Italy), there is a fuelling station where, more than twenty years ago, a first oil spill occurred, and other NAPLs spills have occurred over time. This area is characterized by the presence of volcanic deposits from the Alban Hills complex [22-24], belonging to the formation of Villa Senni, which consists of two main ignimbrites: "Tufo Lionato" (VSN1) at the bottom and "Pozzolanelle" (VSN2) at the top. The area belongs to the "Alban Hills Hydrogeological Unit" (Figure 1), as shown in the recent hydrogeological map of Rome [25]. The degree of relative permeability is high for both porosity and fracturing.

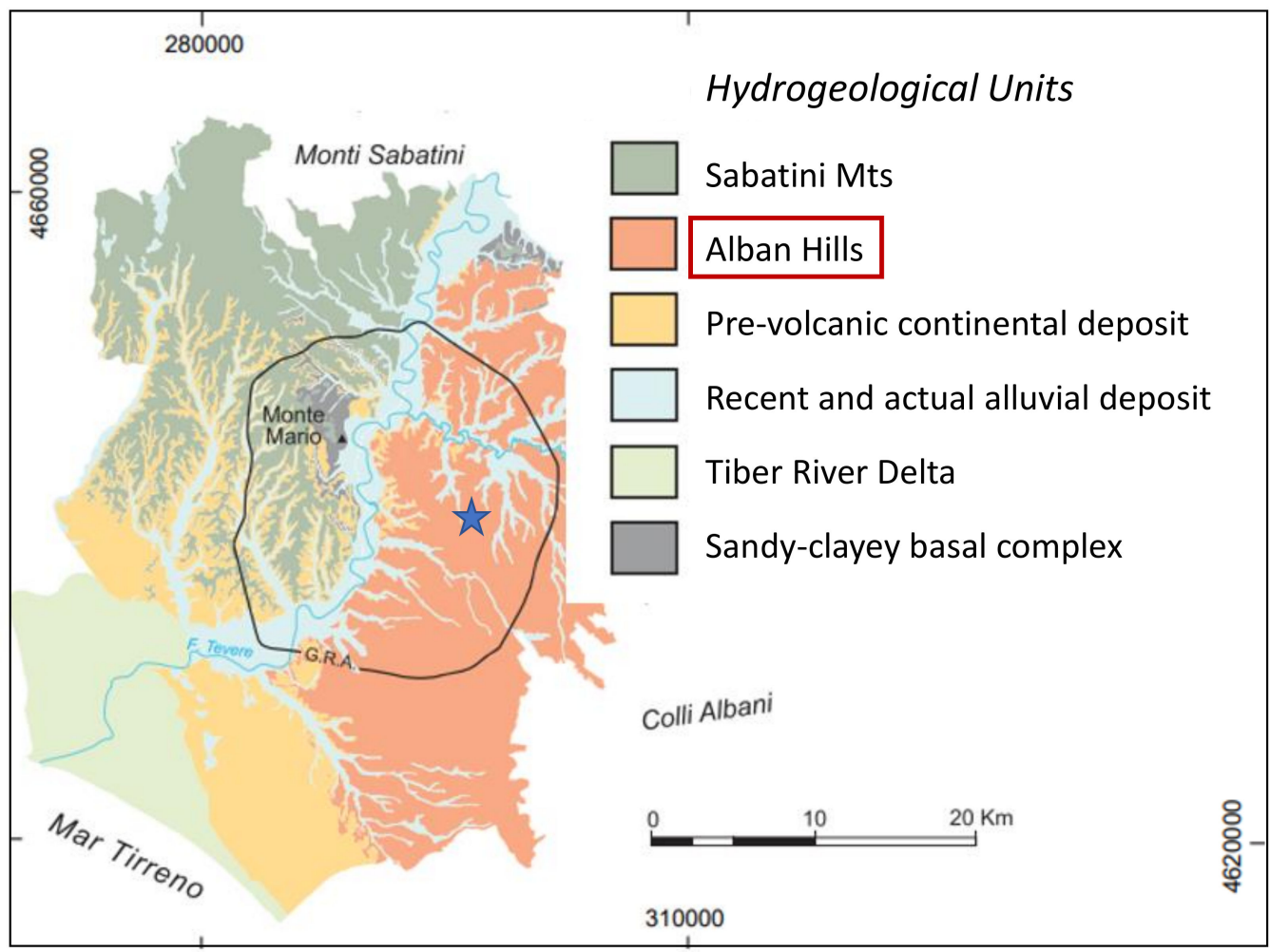

Study area

Figure 1. Map of hydrogeological units (modified from [26]). 
The simplified local stratigraphy, obtained from a drilling carried out in May 2020 to check for the presence of residual Volatile Organic Compounds (VOCs) in a vadose aquifer (Figure 2), generally consists of $4-5 \mathrm{~m}$ of backfill soils and at least $14-15 \mathrm{~m}$ of ignimbrites. Specifically, there is $2 \mathrm{~m}$ of backfill, about $3 \mathrm{~m}$ of reworked pozzolan, $5 \mathrm{~m}$ of pozzolan belonging to the "Pozzolanelle" unit, and about $10 \mathrm{~m}$ of "Tufo Lionato" ignimbrite that is more granular on top and more sandy at the log bottom. The groundwater table can be found at a depth of approximately $18 \mathrm{~m}$, with a seasonal variation of about $0.5 \mathrm{~m}$.

\begin{tabular}{|c|c|c|c|c|}
\hline $\begin{array}{l}\text { DEPTH } \\
(\mathrm{m})\end{array}$ & LITOLOGY & $\begin{array}{l}\text { VOC } \\
100\end{array}$ & 800 & DESCRIPTION \\
\hline $\begin{array}{l}0 \\
-1 \\
-2\end{array}$ & 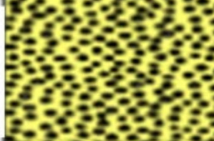 & & & Backfill \\
\hline $\begin{array}{l}-3 \\
-4 \\
-5\end{array}$ & $2<$ & & & $\begin{array}{l}\text { Reworked pozzolan } \\
\text { VOC } 0 \mathrm{ppm}\end{array}$ \\
\hline-6 & & & & Pozzolan (POZZOLANELLE UNIT) \\
\hline $\begin{array}{l}-8 \\
-9 \\
-10\end{array}$ & & & & $\begin{array}{l}\text { Lithoid pozzolan (POZZOLANELLE UNIT) } \\
\text { 8-9 m VOC } 760 \mathrm{ppm} \\
9-10 \mathrm{~m} \text { VOC } 320 \mathrm{ppm}\end{array}$ \\
\hline $\begin{array}{l}-11 \\
-12 \\
-13 \\
-14 \\
-15 \\
-16 \\
-17\end{array}$ & & & & $\begin{array}{l}\text { Lithoid ignimbrite (TUFO LIONATO UNIT) } \\
10-11 \mathrm{~m} \text { VOC } 121 \mathrm{ppm} \\
11-12 \mathrm{~m} \text { VOC } 783 \mathrm{ppm} \\
12-15 \mathrm{~m} \text { VOC } 0 \mathrm{ppm} \\
15-16 \mathrm{~m} \text { VOC } 30 \mathrm{ppm} \\
16-17 \mathrm{~m} \text { VOC } 0 \mathrm{ppm} \\
17-18 \mathrm{~m} \text { VOC } 3.3 \mathrm{ppm}\end{array}$ \\
\hline $\begin{array}{l}-19 \\
-20\end{array}$ & $\equiv=$ & & & $\begin{array}{l}\text { Sandy ignimbrite (TUFO LIONATO UNIT) } \\
18-19 \mathrm{~m} / 19-20 \mathrm{~m} \text { VOC } 33 \mathrm{ppm} / 23 \mathrm{ppm}\end{array}$ \\
\hline
\end{tabular}

Figure 2. Stratigraphic log (SN10) of the study area.

It is worth noting that the groundwater table frequently rises to a depth of about $-9 \mathrm{~m}$ below ground level in two wells (PZ10 and PZ4) located downstream and far from the recharge wells of the "Pump and treat" system, probably due to leaks from the city underground pipeline network, as evidenced by an increasing concentration of chlorinated organic compounds. In particular, Mares S.r.l. found up to $1240 \mathrm{mg} / \mathrm{L}$ of 1,2-dichloroethane in July 2016, demonstrating that, even if low values of substances nowadays represent the urban background, they may reach concentration peaks through fractures and cavities locally intersecting some wells.

\subsection{Remediation System}

The reclamation of the area began in 2016, when a network of 18 sampling wells was set up to screen the extent and evolution of the contamination; of these wells, 14 are located inside the study area, while the other four are placed outside. These outermost wells are used to provide the background values for comparison with those obtained from wells located inside the area (Figure 3). The remediation scheme consists of four abstraction wells of the "pump \& treat" system, and the other five are recharge 
wells for the reintroduction of treated water. "Pump and treat" is a common method for cleaning up groundwater contaminated with dissolved chemicals, including industrial solvents, metals, and fuel oil [26]. In the study area, groundwater is pumped from the abstraction wells to a treatment system consisting of activated carbon filters. Treatment occurs above ground, and the cleaned groundwater is re-injected into the subsurface. This reclamation system has been active (and is still active) for about four years. A soil vapor extraction system completes the remediation plant.

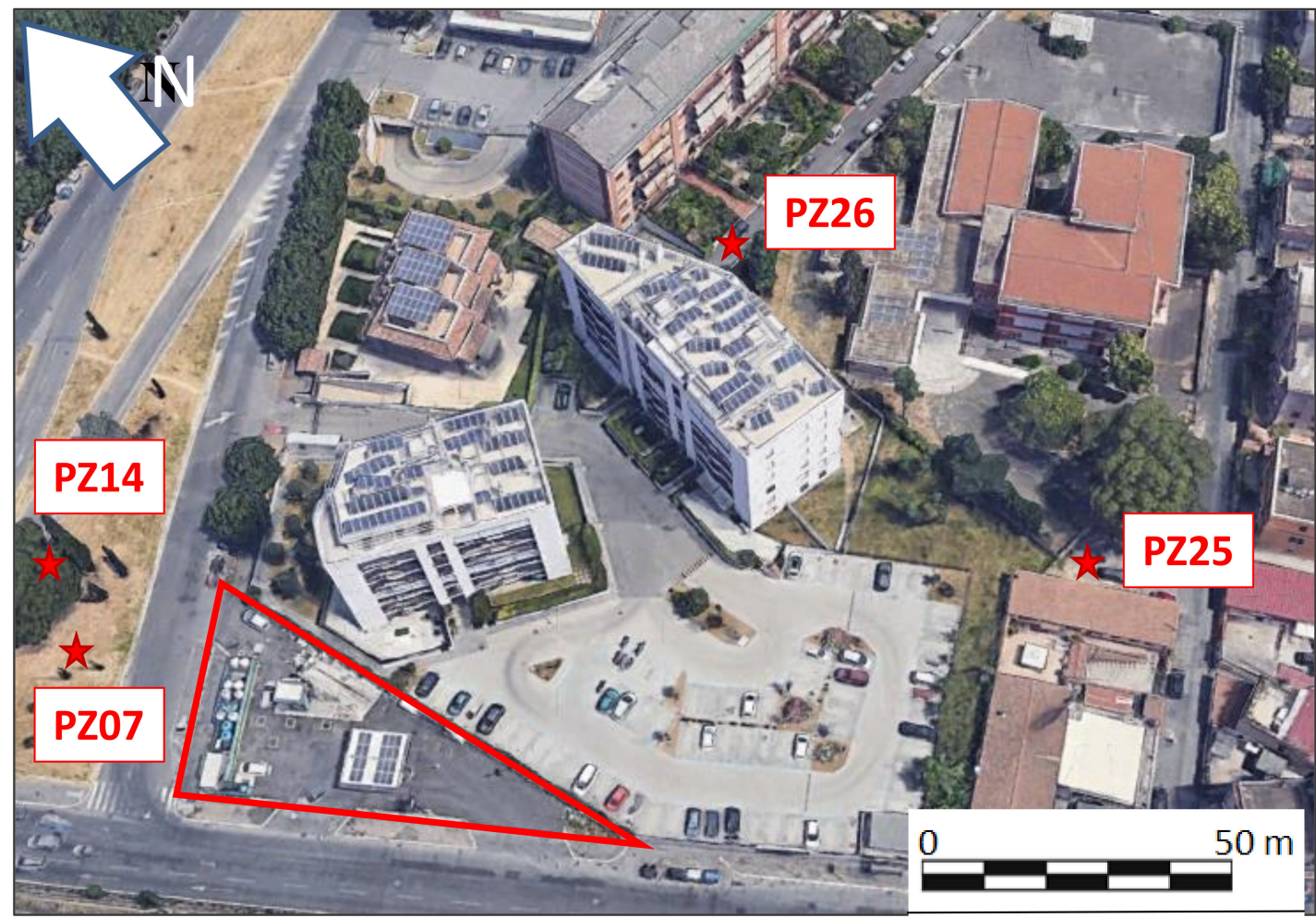

\section{$\star \quad$ Reference piezometers placed outside the area $\triangle$ Fuelling station}

Figure 3. Study area with the location of reference wells placed outside the fuelling station.

\section{Materials and Methods}

\subsection{Field Work}

Two groundwater sampling surveys were carried out in February and May 2020. In both campaigns, samples were taken from 14 wells in the study area and from the other 4 outside the site. No residual NAPLs were detected during the two surveys. Groundwater level was always recorded before extracting from 3 to 5 times the water volume in the wells. This action was necessary to sample groundwater that was really representative of the aquifer conditions in terms of its composition and radon concentration. During the sampling of the water, degassing was avoided by using a flow reducer valve. Polyethylene terephthalate (PET) bottles were used to store water samples for the laboratory determination of radon.

During the field survey (May 2020), continuous core drilling was carried out to check for residual Volatile Organic Compounds (VOCs) in the vadose aquifer and to collect soil samples. This drilling gave us the opportunity to check the local stratigraphy. The VOC levels in ppm were measured using a photoionization detector (PID). PID detectors employ an ultraviolet source to bombard gas samples, allowing them to detect a broad range of VOCs. 


\subsection{Laboratory Methods}

The radon activity concentration in the groundwater was measured using a RAD7 monitor (Durridge Company Inc., Billerica, MA, USA) with a Big Bottle RAD H2O accessory.

\section{Radon Measurements and Data Processing}

The radon activity concentration in the water samples collected in 500- or 660-mL PET bottles was measured using the RAD7 equipped with the Big Bottle RAD H2O accessory. This experimental set-up has been extensively and thoroughly described in earlier studies [6-9,11,27-29]. It consists of several components: the PET bottle, the bubble trap, the aeration system, the temperature data logger, vinyl tubing with an aeration stone fixed at its lower end and a cap at the upper end, the laboratory dryer, and the RAD7. The experimental apparatus is shown in Figure 4. Two cycles of 15 min each have been set for the analysis.

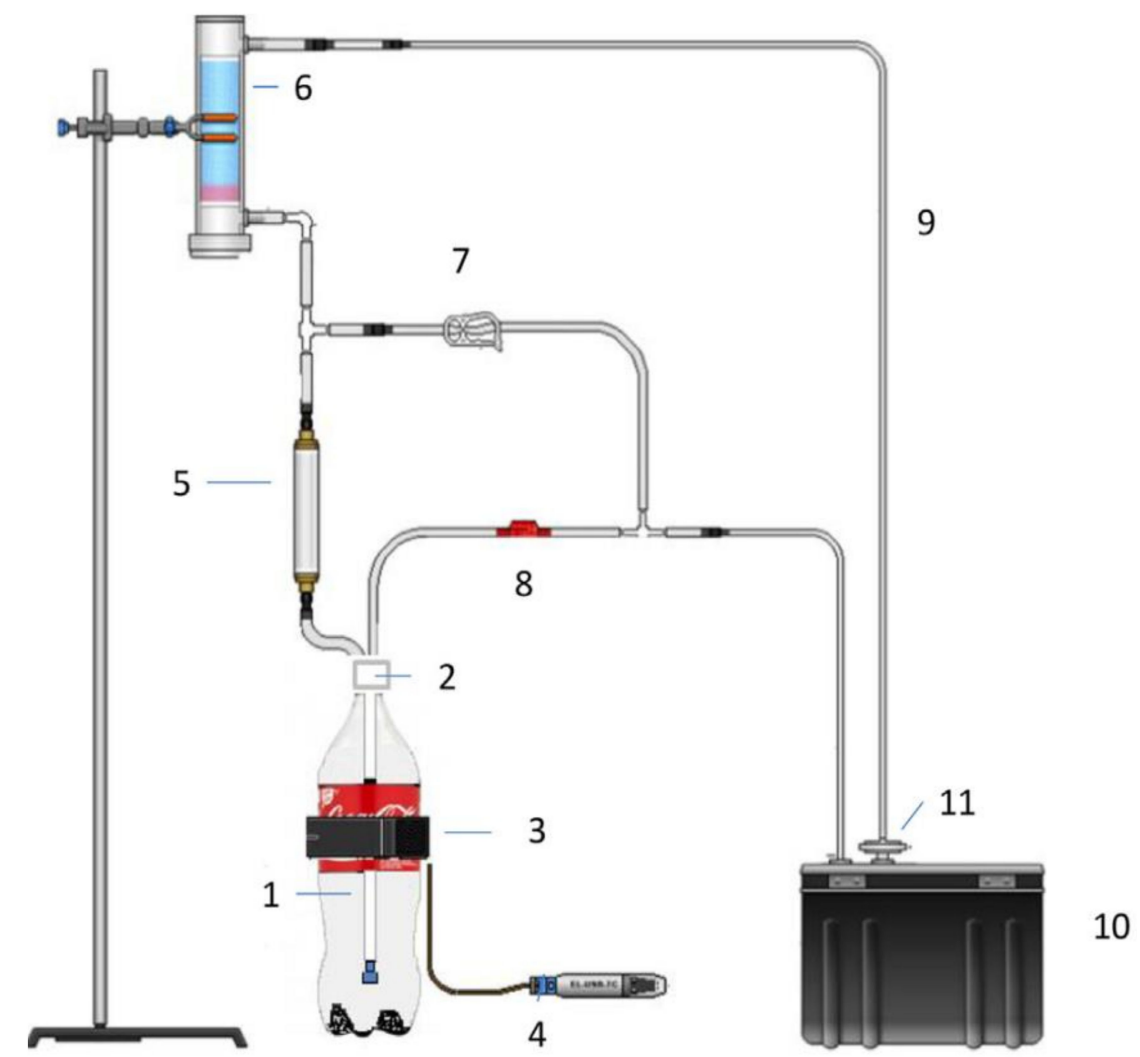

Figure 4. RAD7 monitor with the Big Bottle RAD H2O accessory: (1) plastic soda bottle; (2) screw-on Teflon aerator with a single air stone; (3) elastic clinching strap; (4) temperature data logger; (5) bubble trap; (6) laboratory dryer; (7) clip; (8) check valve; (9) vinyl tubing; (10) RAD7 radon detector; (11) inlet filter (after [6]).

Radon data obtained from the water analyses were used to produce a dot map of the average radon activity concentration in the groundwater during the study period.

\section{Results}

The radon activity concentrations of the groundwater from the 18 wells are reported in the Supplementary Material (Table S1). The results of the radon determination carried out in February and May 2020 show the concentration ranging between 40 (well 13 in May 2020) and 180 Bq/L (well 14 in May 2020). Higher values were found in the external sampling wells 7, 14, 25, and 26 (see Figure 3 for locations), as they were located away from the contamination, while the lowest radon values were measured in some wells within the study area (wells 2, 4, 8, 9, 10, 13, and 19; see Figure 5). 
Radon data higher than $100 \mathrm{~Bq} / \mathrm{L}$ placed upgradient or to the side of PZ13 (adjacent to the removed leaking underground tanks) were used to calculate the average radon in the clean wells $(112 \mathrm{~Bq} / \mathrm{L}$ in February 2020 and 128 Bq/L in May 2020). This concentration (the background radon) was then employed as a reference value to estimate the radon deficit of "dirty" wells (see Table S1) for the ratio between the radon level of single "contaminated" wells and the background [6].

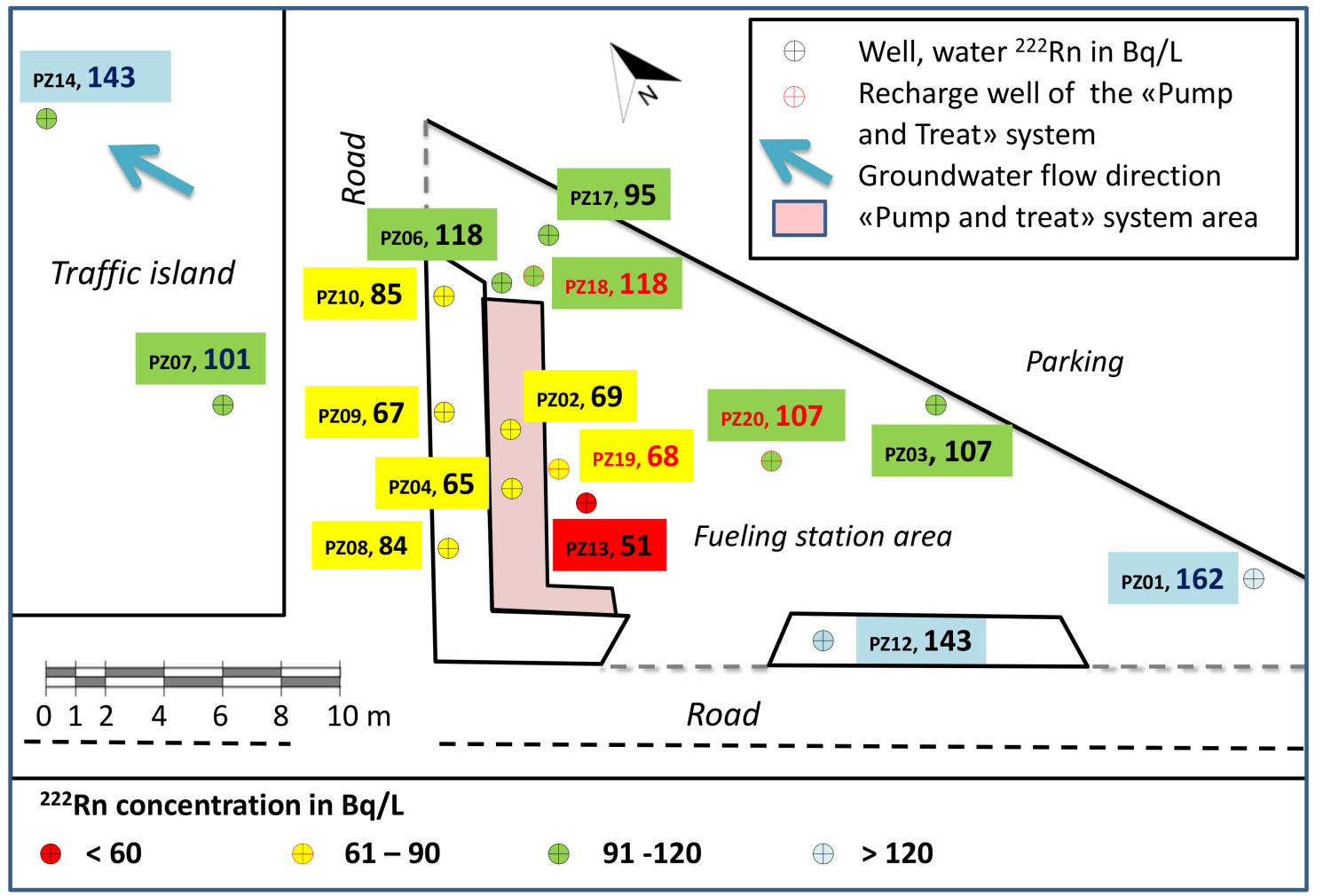

Figure 5. Dot map of the average radon concentrations in the study area obtained from the two sampling campaigns (February and May 2020).

The chemical analyses of the groundwater show that the main residual NAPLs still present in the site are total hydrocarbons, expressed as n-hexane and methyl-tertiary-butyl ether (MTBE), an additive introduced in gasoline in place of lead. MTBE is a hydrophilic ether with a solubility of $50 \mathrm{~g} / \mathrm{L}$ in water, and it is generally 30 times more soluble in water than the hydrocarbon constituents in gasoline [21]. MTBE and other components, commonly known as "oxygenates", are added to gasoline to increase the octane number and reduce the carbon monoxide emissions. MTBE is the main contaminant at the site because it is biologically and chemically stable and thus very persistent in the environment. It is absorbed onto soil grains, such as other residual NAPLs, but its high water solubility and persistence cause it to travel faster and farther than many other components of gasoline when released into an aquifer [6]. It is worth stressing that ${ }^{222} \mathrm{Rn}$ is used here as a natural tracer for monitoring the groundwater contamination by highly soluble MTBE and BTEX because it is highly soluble in a wide range of residual NAPLs, but it is not necessarily soluble in the aqueous solutions of these.

MTBE reached average maximum concentrations of about 2200 and $1700 \mu \mathrm{g} / \mathrm{L}$ in wells 2 and 13, respectively. Furthermore, high mean concentration values of total hydrocarbons were also detected in wells 2 and 13 (values of about 46,000 and 72,000 $\mathrm{gg} / \mathrm{L}$, respectively). Finally, moderate concentrations of benzene and toluene were found, which was in agreement with the MTBE peaks in the same wells. 


\section{Discussion}

The groundwater radon concentrations obtained for the February and May 2020 surveys were used to calculate the average values. With these data, a concentration dot map was drawn (Figure 5). The map shows the radon distribution in the sampled wells.

The average radon concentration is plotted using different colors according to changing values. First of all, it is important to remember that the equilibrium radon concentration in the pore space of an aquifer or soil depends on the aquifer emanation coefficient, the aquifer porosity, the radium activity concentration, and the bulk density of the mineral matrix [4], and that the natural aquifer could not always fulfill these requirements [6,30-32].

The map shows that the residual source zone of contamination is presumably located around well 13 (lowest radon concentration, $51 \mathrm{~Bq} / \mathrm{L}$ ), and that the residual NAPLs source zone, identified by the further very low radon values in wells 2, 4, 8, 9, 10, 19, follows the NNW-SSE flow direction of the aquifer. This is consistent because when light non-aqueous phase liquids (LNAPLs), such as total hydrocarbons or MTBE, infiltrate the soil, being lighter than water they tend to float on top of the water table and therefore follow its flow direction. Nonetheless, it is worth noting that a residual source zone, with low volumes of residual NAPLs occupying the pore space, is confined in the fueling station area and does not extend beyond it, as the higher radon data in wells 7 and 14 suggest.

In addition, if we analyze the relationship between the radon values and the locations of recharge wells, the distribution of the data does not always appear to be simple and clear. There are actually low radon levels downstream of the recharge wells, where you would expect a higher radon concentration, suggesting that an equilibrium between the ${ }^{222} \mathrm{Rn}$ in treated water and ${ }^{226} \mathrm{Ra}$ in the host rock has been reached. Probably, this equilibrium was not achieved because groundwater treated with activated carbon filters and depleted in ${ }^{222} \mathrm{Rn}$ did not have the time necessary to accomplish the full equilibrium (low residence time).

These apparent inconsistencies could also depend on a heterogeneous distribution of ${ }^{226} \mathrm{Ra}$ in the aquifer, the degree of weathering and fracturing, and the emanation coefficient of the rock [30-32]. Finally, it is worth adding that some pumps did not work properly between February and May 2020, and this could have affected the local groundwater level and the flow direction. Generally speaking, the "pump and treat system" worked properly, confining residual NAPLs in the fueling station area.

This finding is supported by the average values (mean of the NAPL levels from February and May 2020 surveys) calculated for the MTBE and total hydrocarbon concentration. The average values exceeding reference limits established by Italian legislation $(40$ and $350 \mu \mathrm{g} / \mathrm{L}$ limits for MTBE and total hydrocarbons, respectively) are reported in a new map (Figure 6). Wells 2, 4, 10, and 13 are the most polluted and are coherently characterized by a very low radon concentration and low radon deficits (Table S1). This scenario highlights that the radon partitioning in NAPLs accurately traces them in the subsoil and is still visible after years.

In order to strengthen the potential of radon-deficits to trace NAPLs distribution, we calculated the equilibrium radon concentration in the Alban Hills Hydrogeological Unit [25] and then compared it to the measured background radon reference. We obtained a calculated value $\left({ }^{222} \mathrm{Rn}_{\mathrm{C}}\right)$ of equilibrium radon concentration in the Alban Hills Hydrogeological Unit [25], characterized by a ${ }^{226}$ Ra activity concentration of the aquifer matrix $\left(\mathrm{A}_{\mathrm{Ra}}, \mathrm{Bq} / \mathrm{kg}\right)$ of 80 , a mineral density $(\rho, \mathrm{kg} / \mathrm{L})$ of 2.65 , a porosity $(\mathrm{n})$ of 0.35 , and an emanation radon efficiency $(\mathrm{E})$ of 0.2 , using the following equation [15]:

$$
{ }^{222} \mathrm{Rn}_{\mathrm{C}}=\mathrm{A}_{\mathrm{Ra}} \times \rho \times \mathrm{E} / \mathrm{n} .
$$

The result of the calculation is $121 \mathrm{~Bq} / \mathrm{L}$, very close to the experimental value $(120 \mathrm{~Bq} / \mathrm{L})$, with averages of 112 and $128 \mathrm{~Bq} / \mathrm{L}$, which are the average radon in the monitoring campaigns of February and May 2020, respectively. 


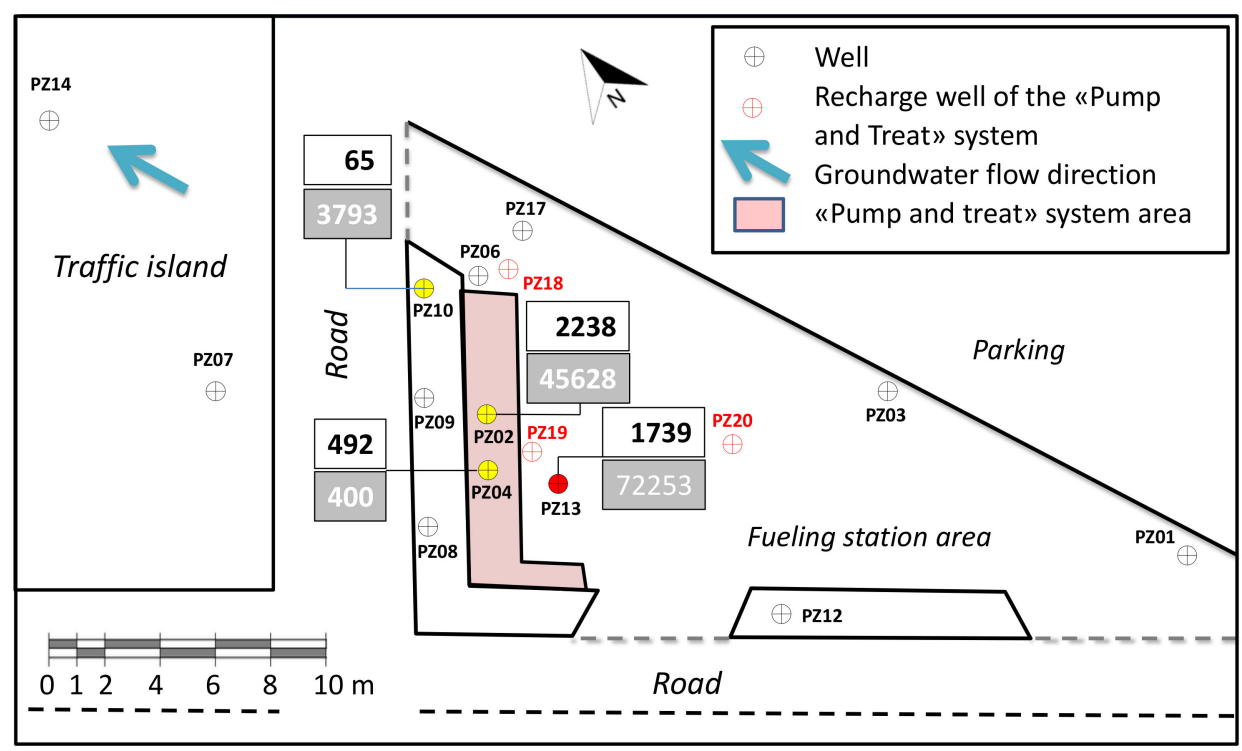

MTBE Total Hydrocarbons Concentration in $\mu \mathrm{g} / \mathrm{L}$

Figure 6. Dot map of the average MTBE and the total hydrocarbon concentrations in the groundwater during the field survey (February-May 2020). We reported only the values of wells where the reference limit was exceeded. Italian law quotes 40 and $350 \mu \mathrm{g} / \mathrm{L}$ as the reference limits for MTBE and total hydrocarbons, respectively.

Another point in favor of the ability of radon-deficits to trace NAPLs contamination arises from the comparison between the average radon deficits in "dirty" wells (wells 2, 4, 8, 9, 10, 13, and 19) of the fueling station in February 2020 (0.63) and the corresponding value of May 2020 (0.54). It is evident that a lower amount of radon was detected in May 2020 in those aquifer domains polluted with residual NAPLs when the sum of the total hydrocarbon and MTBE concentrations reached a higher level $(183,640 \mu \mathrm{g} / \mathrm{L})$, whereas a lower groundwater NAPL concentration $(142,425 \mu \mathrm{g} / \mathrm{L})$ was measured in February 2020.

In situ analyses of VOCs performed on soil samples extracted from the above-mentioned drilling showed that there are concentration peaks both inside the "Pozzolanelle" Unit (between 8 and $9 \mathrm{~m}$ depth) and on the top of the "Tufo Lionato" Unit (between 11 and $12 \mathrm{~m}$ depth). This indicates that, at these depths, there are still hypothetical blobs of residual NAPLs that can be removed by groundwater, as evidenced by chemical analyses of the water samples.

Based on the available information, the following conceptual site model can be proposed (Figure 7). About five years ago, a remediation plant based on a "pump and treat" system, soil vapor extraction, and water re-emission, started in the site where gasoline leakage from underground tanks had occurred, with infiltration throughout the aquifer. Dilution, retardation, degradation, and volatilization processes took place at the same time, causing contaminant attenuation. Regardless, residual NAPLs blobs are still present at depth. They are probably absorbed onto largely abundant zeolite minerals characterizing the ignimbrites [6]. Occasionally, rainfalls wash the terrain and cause the water table to rise, removing hydrocarbons and MTBE to different extents. 


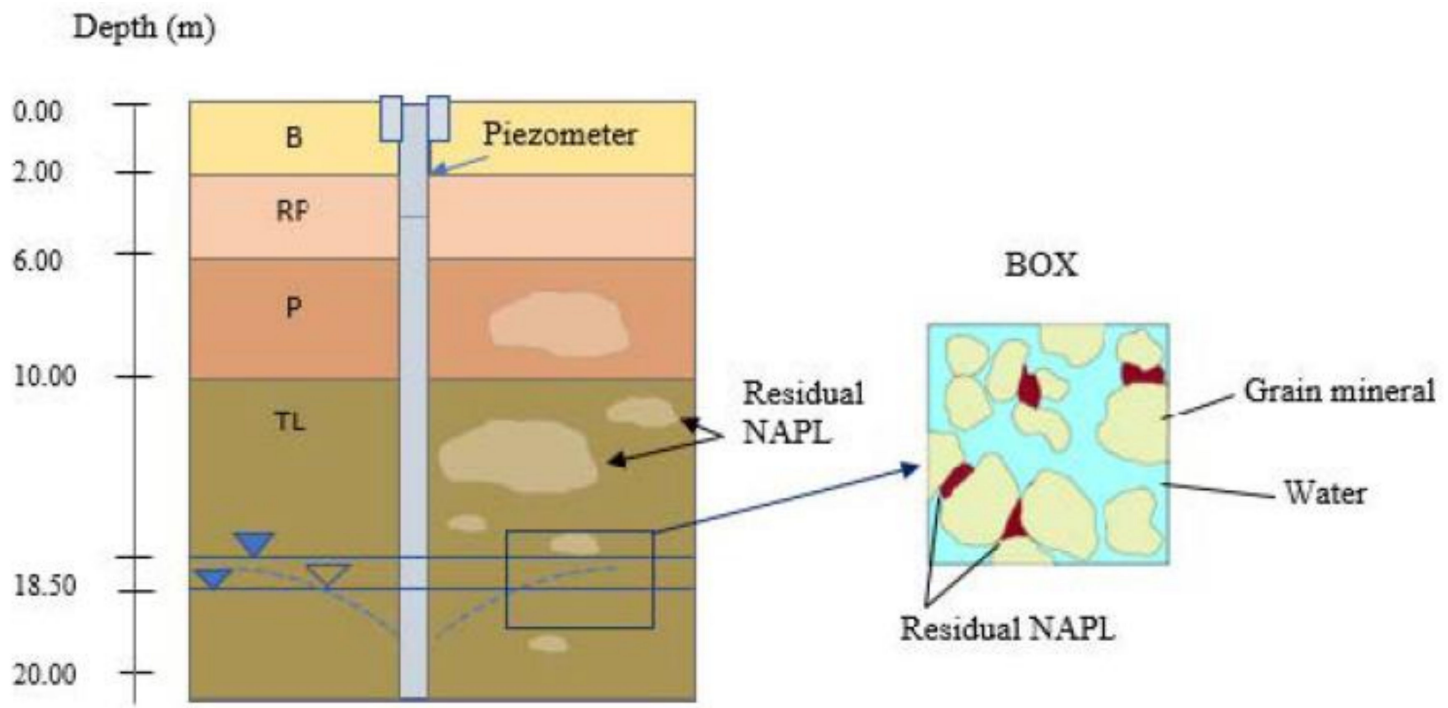

Figure 7. Conceptual site model. B is backfill, RP is reworked pozzolan, $\mathrm{P}$ is pozzolan (pozzolanelle unit), and TL is "Tufo Lionato" unit. Solid lines in TL are the groundwater static levels, while the dashed line is the dynamic level. Box: red blobs are residual NAPLs in the aquifer which are leached by groundwater either when the water table rises or during water pumping.

\section{Conclusions}

More than twenty years ago, the first NAPL spill occurred at the study site. Other spills took place until 2016, when a monitoring and remediation system was activated in the area. In the year 2020, dissolved radon measurements were started in order to use this gas as a natural tracer for NAPL spills. Radon is far more soluble in these substances than in water or air, producing a concentration deficit in those aquifer domains polluted with residual NAPLs compared to the background values in a close and similar uncontaminated area.

The VOC measurements performed on soil samples collected from the drilling highlighted the presence of residual NAPL pockets in the vadose zone at different depths, occasionally removed from groundwater. The presence of these pockets is compatible with the chemical analyses, which show high MTBE and total hydrocarbon concentrations in the water.

A dot map of the average radon concentration in groundwater was produced, suggesting a residual source zone close to the mapped radon minimum zone, well confined in the fueling station area by the "pump and threat" system. This portion of low radon values and low radon deficits corresponds to the places where the dissolved total hydrocarbons and MTBE reach their highest values, also exceeding the reference limits of Italian legislation. The lower average radon deficit allowed us to discriminate the stronger remobilization of NAPLs, which was recorded in the May 2020 survey, compared to the previous one (February 2020).

The residual source zone, although interfered by the pump and treat system, tends to follow the flow direction of the aquifer due to the low density of NAPLs that, once they have infiltrated the subsoil and reached the groundwater table, float on it, following its flow. In places, the low radon levels downstream of the recharge wells are possibly due to the injection of groundwater treated with activated carbon and depleted in radon which did not reach full equilibrium with the ${ }^{226} \mathrm{Ra}$ in the host rock.

Based on that, it is possible to conclude that radon is a powerful and cheap natural tracer of NAPL contamination, providing useful information to study the distribution and evolution of residual blobs of NAPLs in the subsoil and related mobilization processes. Further data are necessary in order to implement the conceptual model of the study site and further explore the potential of radon as a tracer of soil NAPL contamination, as well as as a proxy of groundwater pollution. 
Supplementary Materials: The following are available online at http://www.mdpi.com/2073-4441/12/12/3327/s1: Table S1. Radon activity concentration and radon deficit of groundwater.

Author Contributions: Conceptualization, M.M., P.T., M.S., and C.C.; methodology, M.M. and P.T; investigation, M.M., P.T., and M.S.; resources, M.M. and P.T.; data curation, M.M. and P.T.; writing-original draft preparation, M.M.; writing-review and editing, P.T.; visualization, M.M. and P.T.; supervision, P.T., M.S., C.S. project administration, P.T., M.S., C.S. All authors have read and agreed to the published version of the manuscript.

Funding: This research received no external funding.

Acknowledgments: Authors wish to thank Mares S.r.l. for cooperation in the field work and for providing us with data on the contaminants in groundwater.

Conflicts of Interest: The authors declare no conflict of interest.

\section{References}

1. Semprini, L.; Hopkins, O.S.; Tasker, B.R. Laboratory, field, and modeling studies of Radon-222 as a natural tracer for monitoring NAPL contamination. Transp. Porous Med. 2000, 38, 223. [CrossRef]

2. Schubert, M. Using radon as environmental tracer for the assessment of subsurface non-aqueous phase liquid (NAPL) contaminate on a review. Eur. Phys. J. Special Topics 2015, 224, 717-730. [CrossRef]

3. Krishnaswami, S.; Graustein, W.S.; Turekian, K.K.; Dowd, J.F. Radium, thorium and radioactive lead isotopes in groundwaters: Application to the in-situ determination of adsorption-desorption rate constants and retardation factors. Water Resour. Res. 1982, 18, 1633-1675. [CrossRef]

4. Andrews, J.N.; Wood, D.F. Mechanism of radon release in rock matrices and entry into groundwaters. Inst. Mining Met. Trans. Sect. B 1972, 81, 198-209.

5. Briganti, A.; Voltaggio, M.; Soligo, M.; Tuccimei, P.; Carusi, C.; Lucchetti, C.; Castelluccio, M. Using radon as tracer of an old NAPL contamination in groundwater (Roma, Italy). In Proceedings of the XIV GARRM International Workshop on the Geological Aspects of Radon Risk Mapping, Prague, Czech Republic, 18-20 September 2018.

6. Briganti, A.; Tuccimei, P.; Voltaggio, M.; Carusi, C.; Galli, G.; Lucchetti, C. Assessing methyl tertiary butyl ether residual contamination in groundwater using radon. J. Appl. Geochem. 2020, 116. [CrossRef]

7. Briganti, A.; Voltaggio, M.; Soligo, M.; Tuccimei, P. Assessing the age of a NAPL-spill by Radium isotopes. In Proceedings of the 7th International RaRn Workshop, Delmenhorst, Germany, 2-6 July 2018.

8. Castelluccio, M.; Agrahari, S.; De Simone, G.; Pompilj, F.; Lucchetti, C.; Sengupta, D.; Galli, G.; Friello, P.; Curatolo, P.; Giorgi, R.; et al. Using a multi-method approach based on soil radon deficit, resistivity and induced polarization measurements to monitor NAPL contamination in two study areas in Italy and India. Environ. Sci. Pollut. Res. 2018, 25, 12515-12527. [CrossRef] [PubMed]

9. De Simone, G.; Lucchetti, C.; Pompilj, F.; Galli, G.; Tuccimei, P.; Curatolo, P.; Giorgi, R. Soil radon survey to assess NAPL contamination from an ancient spill. Do kerosene vapors affect radon partition? J. Environ. Radioact. 2017, 171, 138-147. [CrossRef]

10. Cohen, G.; Jousse, F.; Luze, N.; Hohener, P.; Atteia, O. LNAPL source zone delineation using soil gases in a heterogeneous silty-sand aquifer. J. Contam. Hydrol. 2016, 192, 20-34. [CrossRef]

11. De Simone, G.; Galli, G.; Lucchetti, C.; Tuccimei, P. Calibration of Big Bottle RAD H2O set-up for radon in water using HDPE bottles. Radiat. Meas. 2015, 76, 1-7. [CrossRef]

12. Schubert, M.; Freyer, K.; Treutler, H.; Weiss, H. Using the soil gas radon as an indicator for ground contamination by non-aqueous phase-liquids. J. Solids Sediments 2001, 1, 217-222. [CrossRef]

13. Schubert, M.; Freyer, K.; Treutler, H.; Weiss, H. Using radon-222 in soil gas as an indicator of subsurface contamination by non- aqueous phase-liquids (NAPLs). Geofis. Int. 2002, 41, 433-437.

14. Schubert, M.; Pena, P.; Balcazar, M.; Meissner, M.; Lopez, A.; Flores, J.H. Determination of radon distribution patterns in the upper soil as a tool for the localization of subsurface NAPL contamination. Radiat. Meas. 2005, 40, 633-637. [CrossRef]

15. Schubert, M.; Paschke, A.; Lau, S.; Geyer, W.; Knoller, K. Radon as a naturally occurring tracer for the assessment residual NAPL contamination of aquifers. Environ. Pollut. 2007, 145, 920-927. [CrossRef] [PubMed] 
16. De Miguel, E.; Barrio-Parra, F.; Izquierdo-Diaz, M.; Fernandez, J.; Garzia-Gonzalez, J.E.; Alvarez, R. Applicability and limitations of the radon-deficit technique for the preliminary assessment of sites contaminated with complex mixture organic chemicals: A blind filed-test. Environ. Int. 2020, 138, 105591. [CrossRef] [PubMed]

17. Tasker, B.R. Radon-222 as an Indicator for a Nonaqueous Phase Liquids in the Saturated Zone: A Numerical Methods Analysis, Engineering Report. Master's Thesis, Department of Civil Engineering, Oregon State University, Corvallis, OR, USA, 1995.

18. Hunkeler, D.; Hoehn, E.; Hohener, P.; Zeyer, J. ${ }^{222}$ Rn as a partitioning tracer to detect diesel fuel contamination in aquifer: Laboratory study and field observations. Environ. Sci. Technol. 1997, 31, 3180-3187. [CrossRef]

19. Johansson, S.; Fiandaca, G.; Dahlin, T. Influence of non-aqueous phase liquid configuration on induced polarization parameters: Conceptual models applied to a time-domain field case study. J. Appl. Geophys. 2015, 123, 295-309. [CrossRef]

20. Kinner, N.E. Fate, Transport and Remediation of MTBE; University of New Hampshire: Durham, NH, USA, 2001.

21. Kamath, R.; Connor, J.A.; McHugh, T.E.; Nemir, A.; Le, M.P.; Ryan, A.J. Use of long-term monitoring data to evaluate benzene, MTBE, and TBA plume behavior in groundwater at retail gasoline sites. J. Environ. Eng. 2012, 138, 458-469. [CrossRef]

22. Funiciello, R.; Giordano, G. La nuova Carta Geologica di Roma: Litostratigrafia e organizzazione stratigrafica. In La Geologia di Roma: Dal Centro Storico alla Periferia. Memorie Descrittive della Carta Geologica d'Italia; B.E.L.C.A.: Firence, Italy, 2008.

23. Ventriglia, U. Geologia del Territorio del Comune di Roma; Amministrazione Provinciale di Roma: Rome, Italy, 2002; pp. 1-767.

24. Giordano, G.; De Benedetti, A.A.G.; Diana, A.; Diano, G.; Gaudioso, F.; Marasco, F.; Miceli, M.; Mollo, S.; Cas, R.A.F.; Funiciello, R. The Colli Albani mafic caldera (Roma, Italy): Stratigraphy, structure and petrology. J. Volcanol. Geoth. Res. 2006, 155, 49-80. [CrossRef]

25. La Vigna, F.; Mazza, R.; Amanti, M.; Di Salvo, C.; Petitta, M.; Pizzino, L.; Pietrosante, A.; Martarelli, L.; Bonfa, I.; Capelli, G.; et al. Groundwater of Rome. J. Maps 2016, 12, 88-93. [CrossRef]

26. Speight, J.G. Remediation technologies. In Natural Water Remediation: Chemistry and Technology; Butterworth-Heinemann: Oxford, UK, 2020; pp. 263-303.

27. De Simone, G.; Lucchetti, C.; Galli, G.; Tuccimei, P. Correcting for H2O interference using a RAD7 electrostatic collection-based silicon detector. J. Environ. Radioact. 2016, 162-163, 146-153. [CrossRef]

28. Lucchetti, C.; De Simone, G.; Galli, G.; Tuccimei, P. Evaluating radon loss from water during storage in standard PET, bio-based PET, and PLA bottles. Radiat. Meas. 2016, 84, 1-8. [CrossRef]

29. Tuccimei, P.; Lane-Smith, D.; Galli, G.; Simko, J.; Cook, I.; Bond, C.E.; Lucchetti, C.; De Simone, G. Our PET project: An unlimited supply of big and small water sample vials for the assay of radon in water. J. Radioanal. Nucl. Chem. 2016, 307, 2277-2280. [CrossRef]

30. Davis, B.M.; Istok, J.D.; Semprini, L. Static and push-pull methods using radon-222 to characterize dense nonaqueous phase liquid saturations. Ground Water 2003, 4, 470-481. [CrossRef] [PubMed]

31. Cranswick, R.H.; Cook, P.G.; Lamontagne, S. Hyporheic zone exchange fluxes and residence times inferred from riverbed temperature and radon data. J. Hydrol. 2014, 519, 1870-1881. [CrossRef]

32. Sukanya, S.; Noble, J.; Joseph, S. Factors controlling the distribution of radon $\left({ }^{222} \mathrm{Rn}\right)$ in groundwater of a tropical mountainous river basin in southwest India. Chemosphere 2021, 263, 128096. [CrossRef]

Publisher's Note: MDPI stays neutral with regard to jurisdictional claims in published maps and institutional affiliations.

(C) 2020 by the authors. Licensee MDPI, Basel, Switzerland. This article is an open access article distributed under the terms and conditions of the Creative Commons Attribution (CC BY) license (http://creativecommons.org/licenses/by/4.0/). 